trial and Dr E MacPherson in helping to set it up; Professor $M$ Timbury for help in setting up the study and in the study group meetings; Nurse A McLaren and Mrs J Duncan for running the study; and Miss $\mathrm{H}$ Ganson for computerising and collating the study results and Mrs C Spy and Miss T Spence for their secretarial help. We also thank the local general practitioners for their cooperation in referring patients to the study.

1 Acheson ED. The clinical syndrome variously called benign myalgic encephalomyelitis, Iceland disease and epidemic neuromyasthenia. Am f Med 1959;26:569-95.

2 Henderson DA, Shelokov A. Epidemic neuromyasthenia-clinical syndrome? N Engl f Med 1959;260:757-64, 814-8.

3 Ramsay AM. Postviral fatigue syndrome: the saga of Royal Free disease. London: Gower, 1986

4 Behan PO, Behan WMH. Postviral fatigue syndrome. CRC Critical Reviews in Clinical Neurobiology 1988;4:157-78.

5 Fegan KG, Behan PO, Bell EJ. Myalgic encephalomyelitis-report of an epidemic. $f R$ Coll Gen Pract 1983;33:335-7.

6 Keighley BD, Bell EJ. Sporadic myalgic encephalomyelitis in a rural practice. F R Coll Gen Pract 1983;33:339-41.

7 Calder BD, Warnock PJ. Coxsackie B infection in a Scottish general practice. $\mathcal{F} R$ Coll Gen Pract 1984;34:15-9.

practice. $\mathcal{F} R$ Coll Gen Pract 1984;34:15-9. analysis of the findings in 50 cases. F Infect 1985;10:211-22.

9 Calder BD, Warnock PJ, McCartney RA, Bell EJ. Coxsackie B viruses and postviral syndrome: a prospective study in general practice. and postviral syndrome: a prospect
$7 R$ Coll Gen Pract 1987;37:11-4.

10 Bell EJ, Irvine KG, Gardiner AJS, Rodger JC. Coxsackie B infection in a general medical unit. Scott Med f 1983;28:157-9.

11 Grist NR, Bell EJ, Follett EA, et al. Diagnostic methods in clinical virology. Oxford: Blackwell, 1979.

12 McCartney RA, Banatgala JE, Bell EJ. Routine use of mu-antibody capture ELISA for the serological diagnosis of coxsackie virus infections. $\mathcal{F}$ Med Virol 1986;19:205-12.

13 Jamal GA, Hansen S. Electrophysiological studies in the postvira fatigue syndrome. $\mathcal{F}$ Neurol Neurosurg Psychiatry 1985;48:691-4.

14 Arnold DL, Bore PJ, Radda GK, Styles P, Taylor DJ. Excessive intracellular acidosis of skeletal muscle on exercise in a patient with postviral exhaustion/fatigue syndrome. Lancet 1984;i:1367-9.

15 Borysiewicz LK, Haworth SJ, Cohen J, Mundin J, Rickinson A,
Sissona JCP. Epstein-Barr virus-specific immune defects in patients with persistent symptoms following infectious mononucleosis. $Q \mathcal{Y}$ (Med 1986.58:111-21.

16 Strauss SE, Tosato G, Armstrong G, et al. Persisting illness and fatigue in adults with evidence of Epstein-Barr virus infection. Ann Intern Med $1985 ; 102: 7-16$

17 Al Kadiry W, Gold RG, Behan PO, Mowbray JF. Analysis of antigens in the circulating immune complexes of patients with coxsackie infections. In: Behan PO, Meulen VT, Rose FC, eds. Immunology of nervous system infections. Holland: Elsevier, 1983:61-7. (Progress in brain research; vol 59 .

18 Hamblin TJ, Hussain J, Akbar An, Tang YC, Smith JL, Jones DB. Immunological reason for chronic ill health after infectious mononucleosis. BMF 1983;287:85-8.

19 Rice GP, Finney DA, Braheny SL, Knobler RL, Sipe JC, Oldstone MB Disease activity markers in multiple sclerosis. $\mathcal{f}$ Neuroimmuno 1984;6:75-84.

20 Dillon MJ, Marshall WC, Dudgeon JA, Steigman AJ. Epidemic neuromyasthenia outbreak among nurses at a children's hospital. $B M \mathcal{F} 1974 ; i: 301-5$.

21 Poole M, Snow P, Paul C. An unexplained illness in West Otago. $N Z$ Med F 1984;97:351-4.

22 Tobi M, Morag A, Ravid Z, et al. Prolonged atypical infection associated with serological evidence of Epstein-Barr virus infection. Lance $1982 ; 1: 61-4$.

23 Dubois RE, Seeley JK, Brus I, et al. Chronic mononucleosis syndrome. South Med f 1984;77:1376-82.

24 Jones JF, Ray G, Minnich LL, Hicks MJ, Kibler R, Lucas D. Evidence for active Epstein-Barr infection in patients with persistent unfor active Epstein-Barr infection in patients with persistent unMed 1985;102:1-7.

25 Barnes D. Mystery disease at Lake Tahoe challenges virologists and clinicians. Science 1986;234:541-4

26 Yousef GE, Bell EJ, Mann GF, et al. Chronic enterovirus infection in patients with postviral fatigue syndrome. Lancet 1988; i:146-50.

27 Archard LC, Bowles NE, Behan PO, Bell EJ, Doyle D. Postviral fatigue syndrome: persistence of enterovirus RNA in muscle and elevated creatine kinase. $\mathcal{F} R$ Soc Med 1988;81:326-9.

28 Archard LC, Peters J, Behan PO, Doyle D, Bowles NE. Detection of Epstein-Barr virus DNA in muscle with the postviral fatigue syndrome, myalgic encephalomyelitis. Fournal of Experimental Clinical Cancer Research 1988;7:3.

(Accepted 1 November 1990)
Centre for Public Health

Research, S-65182

Karlstad, Sweden

Gunnar Lindberg, MD, senior

physician

Department of Cancer

Epidemiology,

Radiumhemmet,

Karolinska Hospital,

Stockholm, Sweden

Gunnar A Eklund, PHD,

professor of epidemiology

\section{Department of}

Community Health

Sciences, University of

Lund, Malmö, Sweden

Bo Gullberg, MA, senior

lecturer in medical statistics

Lennart Råstam, $M D$, senior

lecturer in family medicine

Correspondence and requests for reprints to:

Dr Lindberg.

BMF 1991;302:143-6

\title{
Serum sialic acid concentration and cardiovascular mortality
}

\author{
Gunnar Lindberg, Gunnar A Eklund, Bo Gullberg, Lennart Råstam
}

\section{Abstract}

Objective-To determine whether serum sialic acid concentration may be used to predict short and long term cardiovascular mortality.

Design-Prospective study on all men and women who had their serum sialic acid concentration measured as part of a general health survey in 1964 or in 1965. All were followed up for an average of 20.5 years.

Setting-Geographical part of the county of Värmland, Sweden.

Subjects-Residents in the area participating in a health check up in 1964-5 (27065 men and 28037 women), of whom 372 men ( 169 with incomplete data and 203 lost to follow up) and 345 women (143 and 202 respectively) were excluded; thus 26693 men and 27692 women entered the study. The study sample was restricted to subjects aged 40-74 during any of the 20 years' follow up.

Main outcome measures-Serum sialic acid concentration, serum cholesterol concentration, diastolic blood pressure, body mass index at the general health survey visit; cardiovascular and noncardiovascular deaths during three periods of follow up (0-6 years, 7-13 years, and 14-20 years), according to the Swedish mortality register, in subjects aged 45-74.

Results-Mean serum sialic acid concentration $(\mathrm{mg} / 100 \mathrm{ml})$ was 68.8 (SD 8.0) for men and 69.2 (8.0) for women; the average concentration increasing with age in both sexes. A total of $5639(21 \%)$ men and $3307(12 \%)$ women died during the follow up period, in whom death in $3052(54 \%)$ men and $1368(41 \%)$ women was from cardiovascular causes. During short (0-6 years), medium (7-13 years), and long (14-20 years) term follow up the relative risk of death from cardiovascular disease increased with increasing serum sialic acid concentration. The relative risk $(95 \%$ confidence interval) associated with the highest quartile of sialic acid concentration compared with the lowest quartile was $2.38(2.01$ to $2.83)$ in men and $2.62(1.93$ to 3.57$)$ in women. Similar results were found for deaths from noncardiovascular disease with relative risks of 1.50 $(1.34$ to 2.68$)$ in men and $1.89(1.57$ to 2.28$)$ in women, but these relative risks were significantly lower than those for deaths from cardiovascular disease $(\mathbf{p}<0.001$ and $\mathbf{p}<0.005$ respectively). In multivariate analysis of total mortality and of cardiovascular mortality with sialic acid concentration, serum cholesterol concentration, diastolic blood pressure, and body mass index as independent variables the impact of sialic acid concentration was virtually the same as in univariate analysis.

Conclusion-Serum sialic acid concentration is a strong predictor of cardiovascular mortality. A possible explanation of these findings is that the serum sialic acid concentration may reflect the existence or the activity of an atherosclerotic process, and this may warrant further investigation.

\section{Introduction}

Sialic acid, a family of acetylated derivatives of neuraminic acid, is widely distributed in mammals. It usually occurs as a terminal component at the nonreducing end of carbohydrate chains of glycoproteins 
and glycolipids. ${ }^{1}$ In human plasma a large quantity of sialic acid is found in orosomucoid, $\alpha_{1}$ antitrypsin, haptoglobin, ceruloplasmin, fibrinogen, complement proteins, and transferrin..$^{23}$ Some of these sialylated glycoproteins are called acute phase reactants, and such substances rapidly increase in concentration after the onset of an inflammatory reaction or injury. ${ }^{4}$

A few earlier studies have investigated aspects of the relation between sialic acid concentration and cardiovascular disease. Succari $e t a l^{5}$ and Hrncir et $a l^{6}$ found raised serum concentrations of sialic acid in patients with acute myocardial infarction. The sialic acid concentration is higher in subjects with diabetes than in those without diabetes ${ }^{7}$ and in subjects with diabetic microangiopathies and macroangiopathies than in subjects with diabetes with no complications. ${ }^{8}$ To our knowledge, however, no prospective studies have investigated the impact of serum sialic acid concentration on mortality from cardiovascular diseases.

The aim of this study was to investigate whether serum sialic acid concentration could be used as a predictor of cardiovascular mortality during short term and long term follow up of a general Swedish population.

\section{Subjects and methods} STUDY POPULATION

During 1962-5 a general health survey was carried out among residents of a geographical part of the county of Värmland, Sweden..$^{10}$ All inhabitants aged 25 years or older were offered a medical check up, including measurement of blood pressure, height, and weight. Blood and urine tests were performed, one of which was the measurement of serum sialic acid concentration. As the method for serum sialic acid analysis was changed during 1963 we restricted our study to the population aged $25-74$ screened in 1964 or in 1965. Altogether, 27065 men and 28037 women participated.

\section{SCREENING PROCEDURES}

About $15 \mathrm{ml}$ of blood was taken from non-fasting subjects into two glass tubes and left to clot for an hour at room temperature. The samples were then centrifuged and aliquots of the serum decanted into disposable plastic containers. Samples chilled in ice were sent overnight to the laboratory for analysis. All chemical analyses were run on an automatic analyser (AutoChemist). Svennerholm's method was used to measure the serum sialic acid concentration, ${ }^{11}$ and cholesterol was analysed according to a modified Liebermann-Burchard method described by Zak et al. ${ }^{12}$ Diastolic blood pressure was measured to the nearest

TABLE I-Age, sex distribution and number of subjects excluded among survey participants in study cohort

\begin{tabular}{|c|c|c|c|c|}
\hline & \multicolumn{2}{|c|}{ Subjects excluded from survey } & \multirow[b]{2}{*}{$\begin{array}{l}\text { Residual survey } \\
\text { participants }\end{array}$} & \multirow{2}{*}{$\begin{array}{l}\text { Study sample } \\
\text { contributing to } \\
\text { person years }\end{array}$} \\
\hline & $\begin{array}{l}\text { Data incomplete } \\
\text { or missing }\end{array}$ & $\begin{array}{l}\text { Lost to } \\
\text { follow up }\end{array}$ & & \\
\hline \multicolumn{5}{|c|}{ Men } \\
\hline Age (years): & & & & \\
\hline $25-34$ & 37 & 75 & 4932 & 4814 \\
\hline $35-44$ & 49 & 54 & 6512. & 6467 \\
\hline $45-54$ & 45 & 36 & 6421 & 6421 \\
\hline $55-64$ & 20 & 19 & 5574 & 5574 \\
\hline $65-74$ & 18 & 19 & 3254 & 3254 \\
\hline \multirow[t]{2}{*}{ Total } & 169 & 203 & 26693 & 26530 \\
\hline & & Women & & \\
\hline Age (years): & & & & \\
\hline $25-34$ & 26 & 70 & 5356 & 5282 \\
\hline $35-44$ & 41 & 46 & 6638 & 6612 \\
\hline $45-54$ & 26 & 33 & 6451 & 6451 \\
\hline $55-64$ & 33 & 35 & 5888 & 5888 \\
\hline $65-74$ & 17 & 18 & 3359 & 3359 \\
\hline Total & 143 & 202 & 27692 & 27592 \\
\hline
\end{tabular}

TABLE II -Number of person years generated during 20.5 years of follow up in men and women

\begin{tabular}{|c|c|c|}
\hline & Men & Women \\
\hline \multicolumn{3}{|c|}{ Age (years) during follow up: } \\
\hline $45-54$ & 122116 & 126975 \\
\hline $55-64$ & 120946 & 128208 \\
\hline $65-74$ & 86481 & 100482 \\
\hline Total & 329543 & 355665 \\
\hline
\end{tabular}

TABLE III - Distribution of sialic acid concentration in participants of the survey. Figures are numbers (percentages)

\begin{tabular}{|c|c|c|}
\hline $\begin{array}{l}\text { Sialic acid concentration } \\
(\mathrm{mg} / 100 \mathrm{ml})\end{array}$ & Men & Women \\
\hline$\leqslant 54$ & $54(0 \cdot 2)$ & $39(0 \cdot 1)$ \\
\hline $55-59$ & $1617(6 \cdot 1)$ & $1475(5.3)$ \\
\hline $60-64$ & $5644(21 \cdot 1)$ & $5478(19.8)$ \\
\hline $65-69$ & $7207(27 \cdot 0)$ & $7470(27 \cdot 0)$ \\
\hline $70-74$ & $5485(20 \cdot 5)$ & $5704(20 \cdot 6)$ \\
\hline $75-79$ & $3597(13.5)$ & $3930(14 \cdot 2)$ \\
\hline $80-84$ & $2046(7 \cdot 7)$ & $2419(8 \cdot 7)$ \\
\hline $85-89$ & $581 \quad(2 \cdot 2)$ & $683(2 \cdot 5)$ \\
\hline $90-94$ & $239(0.9)$ & $275(1.0)$ \\
\hline $95-99$ & $118(0.4)$ & $120(0.4)$ \\
\hline$\geqslant 100$ & $105(0.4)$ & $99(0.4)$ \\
\hline & 26693 & 27692 \\
\hline
\end{tabular}

TABLE IV-Numbers of participants and mean (standard deviation) sialic acid concentration by age

\begin{tabular}{|c|c|c|c|c|}
\hline \multirow[b]{2}{*}{$\begin{array}{c}\text { Age } \\
\text { (years) }\end{array}$} & \multicolumn{2}{|r|}{ Men } & \multicolumn{2}{|c|}{ Women } \\
\hline & No & $\begin{array}{c}\text { Mean }(\mathrm{SD}) \\
\text { sialic acid } \\
\text { concentration } \\
(\mathrm{mg} / 100 \mathrm{ml})\end{array}$ & No & $\begin{array}{c}\text { Mean }(\mathrm{SD}) \\
\text { sialic acid } \\
\text { concentration } \\
(\mathrm{mg} / 100 \mathrm{ml})\end{array}$ \\
\hline $25-29$ & 2296 & $67 \cdot 0(7 \cdot 05)$ & 2541 & $67 \cdot 4(7 \cdot 38)$ \\
\hline $30-34$ & 2636 & $67.3(6.81)$ & 2815 & $67.0(6.98)$ \\
\hline $35-39$ & 2997 & $67 \cdot 4(7 \cdot 31)$ & 3140 & $67 \cdot 2(7 \cdot 08)$ \\
\hline $40-44$ & 3515 & $68.0(7.39)$ & 3498 & $67 \cdot 6(7 \cdot 02)$ \\
\hline $45-49$ & 3200 & $68 \cdot 4(7 \cdot 66)$ & 3141 & $68 \cdot 1(7 \cdot 43)$ \\
\hline $50-54$ & 3221 & $69 \cdot 0(7 \cdot 89)$ & 3310 & $69 \cdot 7(7 \cdot 90)$ \\
\hline $55-59$ & 3013 & $69 \cdot 7(8 \cdot 29)$ & 3209 & $70 \cdot 7(8 \cdot 18)$ \\
\hline $60-64$ & 2561 & $70.5(8.69)$ & 2679 & $71 \cdot 8(8.60)$ \\
\hline $65-69$ & 1946 & $71 \cdot 2(8 \cdot 94)$ & 2011 & $72 \cdot 8(8 \cdot 57)$ \\
\hline $70-74$ & 1308 & $72 \cdot 2(9 \cdot 22)$ & 1348 & $74.0(8 \cdot 75)$ \\
\hline
\end{tabular}

$5 \mathrm{~mm} \mathrm{Hg}$. Height was measured to the nearest centimetre and weight to the nearest kilogram. Data were incomplete or missing in 169 men and in 143 women, including a few subjects in whom the personal identification number was missing or uninterpretable.

\section{MORTALITY DURING FOLLOW UP}

The Swedish mortality register includes data on the cause of death in all subjects living in Sweden at the time of their death. We used this register, which has very few omissions, ${ }^{13}$ to identify fatal events in our study cohort, and all deaths occurring during 1964-85 were considered in our analysis. The underlying cause of death is coded by trained staff according to the International Classification of Diseases, the seventh revision ${ }^{14}$ being used for deaths occurring from 1964 to 1968 and the eighth revision ${ }^{15}$ for deaths occurring in 1969 or later. In the seventh edition cardiovascular death is defined by the codes $330-334,420$, or 422 and in the eighth edition by the codes $410-413$ or $430-438$.

Survey participants recorded in the original survey register were linked to the mortality register and to the 1980 national census register to check for subjects lost to follow up. A survey participant missing from the two registers was categorised as lost to follow up and excluded from further analysis (203 men and 202 women).

Table I summarises the number, age, and sex of subjects who were excluded from the analysis of the study cohort. Data were complete for $98.8 \%$ of those subjects who originally participated in the survey 
(27065 men and 28037 women), altogether, corresponding to $78 \%$ of men and $81 \%$ of women of the total population at risk, based on the 1960 census.

Deaths occurring only between the ages of 45 and 74 years in subjects who were aged 25-74 at the time of the health examination were included in the analysis. Consequently, the study sample was restricted to those subjects who were aged 45-74 during any of the 20 years of follow up.

\section{STATISTICAL METHODS}

Quartiles of sialic acid concentration were determined for each five year age stratum at screening (25-29, $30-34, \ldots 70-74)$, and these age-adjusted quartiles formed the basis for further analysis. Mortality was standardised to the age distribution of the total follow up person years to give the mortality for each follow up period. Mortality during three follow up periods (0-6 years, $7-13$ years, and $14-20$ years) was calculated for each quartile of sialic acid concentration. Average

TABLE $\mathrm{V}-$ Age standardised mortality per 1000 person years (number of deaths) by quartile interval of serum sialic acid concentration in subjects aged 45-74 at follow up

\begin{tabular}{|c|c|c|c|c|}
\hline \multirow{2}{*}{$\begin{array}{c}\text { Follow up } \\
\text { (years) }\end{array}$} & \multicolumn{4}{|c|}{ Serum sialic acid concentration quartile } \\
\hline & $<1$ & $1-2$ & $2-3$ & $3-4$ \\
\hline \multicolumn{5}{|c|}{ Total mortality $(\mathrm{men})$} \\
\hline $0-6$ & $12 \cdot 6(312)$ & $12 \cdot 9(321)$ & $16 \cdot 3(401)$ & $23 \cdot 7(567)$ \\
\hline $7-13$ & $14 \cdot 6(431)$ & $15 \cdot 0(442)$ & $18.0(512)$ & $23 \cdot 2(624)$ \\
\hline $14-20$ & $13 \cdot 1(402)$ & $16 \cdot 8(505)$ & $17 \cdot 5(511)$ & $23 \cdot 1(611)$ \\
\hline \multicolumn{5}{|c|}{ Total mortality (women) } \\
\hline $0-6$ & $7 \cdot 5(185)$ & $7 \cdot 5(191)$ & $9 \cdot 9(224)$ & $14 \cdot 6(364)$ \\
\hline $7-13$ & $7 \cdot 2(229)$ & $7 \cdot 4(235)$ & $9 \cdot 8(306)$ & $12 \cdot 6(375)$ \\
\hline $14-20$ & $6 \cdot 8(230)$ & $8 \cdot 0(270)$ & $9 \cdot 4(306)$ & $12 \cdot 1(372)$ \\
\hline \multicolumn{5}{|c|}{ Cardiovascular mortality (men) } \\
\hline $0-6$ & $6 \cdot 1(150)$ & $5 \cdot 9(148)$ & $8 \cdot 4(205)$ & $12 \cdot 6(299)$ \\
\hline $7-13$ & $7 \cdot 3(218)$ & $7 \cdot 9(232)$ & $10 \cdot 5(298)$ & $14 \cdot 3(384)$ \\
\hline $14-20$ & $7 \cdot 0(219)$ & $9 \cdot 0(270)$ & $9 \cdot 6(280)$ & $13 \cdot 1(349)$ \\
\hline \multicolumn{5}{|c|}{ Cardiovascular mortality (women) } \\
\hline $0-6$ & $2 \cdot 7 \quad 68)$ & $2 \cdot 7(69)$ & $3.8(95)$ & $6 \cdot 4(154)$ \\
\hline $7-13$ & $2 \cdot 9(93)$ & $2 \cdot 8 \quad(89)$ & $3.9(123)$ & $5.9(175)$ \\
\hline $14-20$ & $2.5(86)$ & $3 \cdot 3(111)$ & $4 \cdot 2(141)$ & $5 \cdot 3(164)$ \\
\hline
\end{tabular}

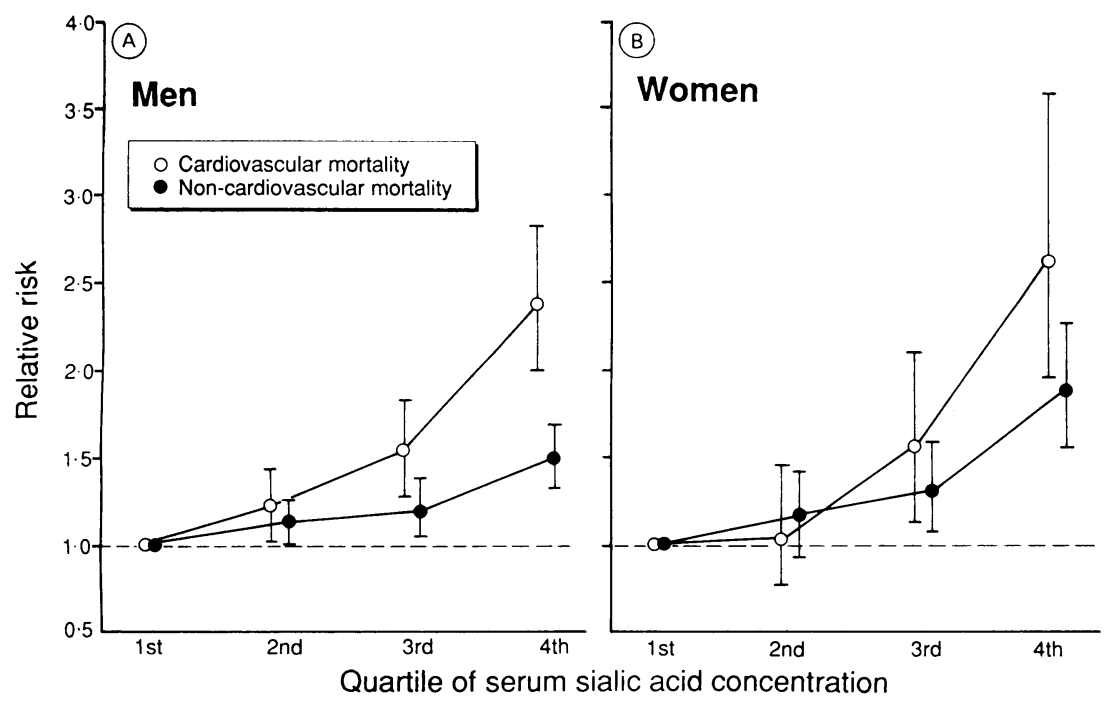

Age adjusted relative risks of cardiovascular and non-cardiovascular mortalities by quartile of serum sialic acid concentration among men (a) and women (b) aged 45-74 at follow up. Bars are $95 \%$ confidence intervals

TABLE VI-Mean (standard deviation) diastolic blood pressure, total serum cholesterol concentration, and body mass index in men and women aged 25-74 and correlations of each variable with serum sialic acid concentration

\begin{tabular}{|c|c|c|c|c|}
\hline & \multicolumn{2}{|c|}{ Men } & \multicolumn{2}{|c|}{ Women } \\
\hline & Mean (SD) & Correlation & Mean $(\mathrm{SD})$ & Correlation \\
\hline Diastolic blood pressure $(\mathrm{mm} \mathrm{Hg})$ & $87 \cdot 3(12 \cdot 8)$ & $0 \cdot 14$ & $89 \cdot 0(14 \cdot 0)$ & $0 \cdot 22$ \\
\hline Total serum cholesterol $(\mathrm{mmol} / \mathrm{l})$ & $6.45(0.96)$ & 0.09 & $6.62(1.05)$ & $0 \cdot 12$ \\
\hline Body mass index $\left(\mathrm{kg} / \mathrm{m}^{2}\right)$ & $25 \cdot 1 \quad(3.0)$ & $0 \cdot 11$ & $24 \cdot 9 \quad(3 \cdot 8)$ & $0 \cdot 24$ \\
\hline
\end{tabular}

follow up during the first year - that is, from the date of participation in the health examination to 31 December of the same year-was 0.55 years. The average follow up time was therefore 20.55 years. Statistical testing of relative risk estimates was performed with a weighted regression model. The best fit was achieved by assuming a normal error distribution for the logarithmic transformed rates. Number of person years was entered as weights in the computations (generalised linear interactive modelling $\left.(\mathrm{GLIM})^{16}\right)$.

Body mass index was calculated as weight $(\mathrm{kg}) /$ (height $(\mathrm{m}))^{2}$

\section{Results}

Of the 26693 men and 27692 women included for follow up, 163 men and 100 women died before the age of 45 and consequently did not contribute person years to this study (table I). The total cohort followed up comprised 329543 person years for men and 355665 person years for women (table II).

The mean serum sialic acid concentration was 68.8 $(\mathrm{SD} 8 \cdot 0) \mathrm{mg} / 100 \mathrm{ml}$ in men and $69 \cdot 2(8 \cdot 0) \mathrm{mg} / 100 \mathrm{ml}$ in women. Table III shows the distributions of serum sialic acid concentration for men and women. The distribution was skewed to the right for both sexes but was strictly unimodal like that of several other risk factors, such as blood pressure and serum cholesterol concentration. Table IV shows the mean (SD) serum sialic acid concentration by sex and by five year age group. It is evident that the average sialic acid concentration increased with age.

A total of $5639(21 \%)$ men and $3307(12 \%)$ women, died during follow up, in whom death in $3052(54 \%)$ men and $1368(41 \%)$ women was of cardiovascular origin. Increasing total mortality occurred from the lowest to the highest of the sialic acid concentrations in both men and women. After standardisation for age this pattern was virtually consistent among the three, seven year periods of short, medium, and long term follow up (table V). The same was true for cardiovascular mortality

As only minor differences were found in mortality among the three periods of follow up and no interaction with age was found we considered it justifiable to merge the results for all the years when further analysing the data. The figure shows the relative risk for cardiovascular and non-cardiovascular mortality (total mortality minus cardiovascular mortality) during 0 to 20 years of follow up in men and in women. This relative risk increased for men, irrespective of the cause of death, from the lowest to all higher quartiles, but in women a significant increase was found only between the second and fourth quartiles compared with up to the first quartile. There was a significantly increasing trend for both sexes over all quartiles, irrespective of the cause of death $(\mathrm{p}<0.001$ for cardiovascular deaths and $\mathrm{p}<0.001$ for non-cardiovascular deaths in men, and $p<0.001$ for both in women). The relative risk for cardiovascular death increased significantly more when correlated with quartile of sialic acid concentration than did the risk for non-cardiovascular death in men $(\mathrm{p}<0.001)$ and in women $(\mathrm{p}<0.05)$.

\section{MULTIVARIATE ANALYSIS}

Table VI shows the mean diastolic blood pressure, total serum cholesterol concentration, and body mass index for men and for women. The correlations between sialic acid concentration and each of these risk factors for cardiovascular disease were generally low but significant for both sexes. In a multivariate analysis of cardiovascular mortality with sialic acid concentration, total serum cholesterol concentration, diastolic blood pressure, and body mass index as independent 
variables the impact of sialic acid concentration changed only marginally compared with that shown for univariate analysis. For example, the relative risk between the third and fourth quartile of sialic acid concentration in men decreased from $2 \cdot 38$ to $2 \cdot 07$. The same was true for total mortality.

\section{Discussion}

A few case-control studies showed that serum sialic acid concentration is higher in patients with acute myocardial infarction ${ }^{5}$ and have suggested that there is a lag between the acute event and the rising concentration. ${ }^{6}$ These findings do not, however, justify any firm conclusions about the direction of the relation, that is, whether a high serum sialic acid concentration predicts future cardiovascular mortality or whether it is caused by the acute condition.

Our study showed a strong and consistent association between a single randomly measured serum sialic acid concentration and cardiovascular mortality during an average of 20.5 years of follow up in both men and women. The magnitude of the relative risk was similar to that for serum cholesterol concentration in this population, ${ }^{17}$ and there was a clear and uniform dose-response relation. This relation may, however, have been caused by a confounder that is highly correlated to serum sialic acid concentration but was not controlled for in this study. The link between mortality and the sialic acid concentration measured on one occasion remained unchanged for several years. Such a potential confounder must therefore have remained active during a similarly extended time frame. None of the classic risk factors for cardiovascular disease that were controlled for in this study had a high enough correlation with sialic acid concentration to support this explanation. This was confirmed by results of the multivariate analysis.

There was a significant but weaker relation between serum sialic acid concentration and non-cardiovascular mortality. This may be explained either by a true causal relation, with the limitations described above for cardiovascular mortality, or by systematic misclassification of the cause of death - for example, in the case of multiple causes of death. Supporting the second explanation is the fact that this relation was equally consistent over the entire follow up period, which contradicts the suggestion that the risk related to higher concentrations of sialic acid reflects an acute phase activity - for example, in the case of an existing cancer. ${ }^{18}$

The reliability of a sialic acid concentration measured on one occasion can be affected firstly, by the precision of the test and by methods of analysis and, secondly, by short and long term intraindividual variability. These sources of error would all weaken the relation, as would errors resulting from random misclassification of the cause of death. Thus it is reasonable to assume that our results exist despite possible errors of measurement and classification and not because of them.

Smoking habit is an obvious possible confounder that we could not adjust for as data on tobacco consumption were not available. Krolikowski et al found that 20 non-smoking patients had marginally higher serum sialic acid concentrations than six patients who smoked, ${ }^{19}$ but we are unaware of any other studies to investigate the link between serum sialic acid concentration and smoking. That study, though small, contradicted smoking as a confounder in this context. Other possible confounders are coagulation factors such as plasma fibrinogen, which is a recognised acute phase reactant and sialic acid carrier in plasma ${ }^{2}$ that has been linked with cardiovascular morbidity..$^{21-22}$ The triglyceride concentration also has to be considered as Radhakrishnamurthy $e t$ al found a moderately high correlation $(r=0.42)$ between serum triglyceride concentration and serum sialic acid concentration in 65 patients with diabetes. ${ }^{7}$ Further investigation of these possible sources of bias is therefore needed.

Many acute phase reactants contain sialic acid. ${ }^{23}$ Taniuchi et al estimated a correlation of 0.9 between the serum concentrations of sialic acid and orosomucoid (a serum globulin) and concluded that the measurement of sialic acid in serum seemed to provide a rapid and simple index as acute phase reactants. ${ }^{2}$ An increased concentration of acute phase reactants caused by an acute inflammatory disease or by an injury, however, cannot explain the constant excess mortality during the 20 years after the measurement of sialic acid concentration. Stuart et al have, however, shown a correlation between atherosclerotic peripheral vascular disease and serum globulin concentration. ${ }^{24}$ Thus one possible explanation of our results might be that the serum sialic acid concentration reflects the existence or maybe even the activity of an atherosclerotic process, which in turn might cause a fatal cardiovascular event several years later.

We thank Dr Per-Henrik Magnusson, who drew our attention to the relation between sialic acid and mortality, and Professor Arne Lundblad for his valuable discussions about carbohydrate chemistry. The study was financially supported by Värmland County Council.

$1 \mathrm{Ng} \mathrm{S}$, Dain JA. The natural occurrence of sialic acids. In: Rosenberg A Schengrund S, eds. Biological roles of sialic acid. New York: Plenum, 1976:59-102.

2 Taniuchi $\mathrm{K}$, Chifu $\mathrm{K}$, Hayashi $\mathrm{N}$, et al. A new enzymatic method for the determination of sialic acid in serum and its application for a marker of determination of sialic acid in serum and its application

3 Petrén S, Vesterberg $\mathrm{O}$. The $\mathrm{N}$-acetylneuraminic acid content of five forms of human transferrin. Biochem Biophys Acta 1989;994:161-5.

4 Schwick HG, Haupt H. Properties of acute phase proteins of human plasma. Behring Inst Mitt 1986;80:1-10.

5 Succari M, Foglietti MJ, Percheron F. Perchlorosoluble glycoproteins and myocardial infarct: modifications of the carbohydrate moiety. Pathol Biol (Paris) 1982;30:151-4.

6 Hrncir Z, Pidrman V, Tichy M, Hamet A. Serum sialic acid in acute myocardial infarction in a dynamic follow up. Vnitr Lek 1975;21(5):436-9.

7 Radhakrishnamurthy B, Berenson GS, Pargaonkar PS, et al. Serum free and protein-bound sugars and cardiovascular complications in diabetes mellitus. Lab Invest 1976;34:159-65.

8 Shvartz LS, Paukman LI. Diabetic angiopathies and mucopolysaccharide metabolism. Probl Endokrinol (Mosk) 1971;17:37-41.

9 National Board of Health and Welfare. The Värmland survey. Stockholm: AB Allmänna Förlaget, 1971.

10 Törnberg SA, Holm LE, Carstensen JM, Eklund GA. Risks of cancer of the colon and rectum in relation to serum cholesterol and beta lipoprotein. $N$ Engl F Med 1986;315:1629-33.

11 Svennerholm L. Quantitative estimation of sialic acids. Biochim Biophys Acto 1957:24:604-11.

12 Zak B, Dickenman RC, White EG, Burnett H, Cherney PJ. Rapid estimation free and total cholesterol. Am f Clin Pathol 1954;24:1307-15.

13 Bolander AM. Mortality statistics in Sweden and its neighbouring countries. Advantages and hazards inherent in systems and materials. In: Boström $\mathrm{H}$, Ljungstedt N, eds. Medical aspects of mortality statistics. Stockholm: Almkvist and Wiksell, 1981:236-55.

14 World Health Organisation. Manual of the international statistical classification of diseases, injuries, and causes of death. 7th Revision. Geneva: WHO, 1955.

15 World Health Organisation. Manual of the international statistical classification of diseases, injuries, and causes of death. 8th revision. Geneva: WHO, 1967.

16 McCullagh P, Nelder J. Generalised linear model. London: Chapman and Hall, 1989.

17 Törnberg SA, Holm L-E, Carstensen JM, Eklund GA. Cancer incidence and cancer mortality in relation to serum cholesterol. 7 NCI 1989;81:1917-21.

18 Shanberger RJ. Serum sialic acid in normals and in cancer patients. 7 Clin Chem Clin Biochem 1984:22:647-51.

19 Krolikowski FJ, Reuter K, Waalkes TP, Sieber SM, Adamson RH. Serum sialic acid levels in lung cancer patients. Pharmacology 1976;14:47-51.

20 Meade TW, North WRS, Chakrabarti R, et al. Haemostatic function and cardiovascular death: early results of a prospective study. Lancet $1980 ; \mathrm{i}: 1050-4$.

21 Swahn E, von Schenck $H$, Wallentin L. Plasma fibrinogen in unstable coronary artery disease. Scan f Clin Lab Invest 1989;49:49-54.

22 Wilhelmsen L, Svärdsudd K, Korsan-Bengsten K, Larsson B, Welin L, Tibblin G. Fibrinogen as a risk factor for stroke and myocardial infarction. NEngl f Med 1984;311:501-5.

23 Varma R, Michos GA, Varma RS. The protein-bound carbohydrates of seromucoid from normal human serum. I Clin Chem Clin Biochem 1983;21:273-7

24 Stuart J, George AJ, Davies AJ, Aukland A, Hurlow RA. Haematological stress syndrome in atherosclerosis. F Clin Pathol 1981;34:464-7

(Accepted 17 October 1990) 